UNIO - EU Law Journal. Vol. 4, No. 1, January 2018, pp 51-66.

(2018 Centre of Studies in European Union Law

School of Law - University of Minho

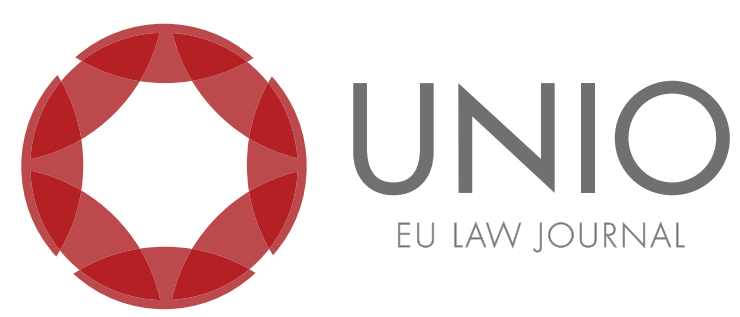

\title{
EU support to domestic prosecution of violations of International Humanitarian Law
}

\section{Bettina Steible*}

ABSTRACT: The Geneva Conventions of 12 August 1949 establish an obligation to ensure respect for International Humanitarian Law (IHL) at all times. This summary obligation is now understood as enshrining a mechanism of collective responsibility whereby all State parties commit to adopt all the necessary and reasonable measures to prevent and stop violations of IHL, but also to prosecute them when they amount to war crimes. This third dimension is comprised in articles 49/50/129/146 of Conventions, which impose an obligation on its State parties to extradite or prosecute (aut dedere aut judicare) alleged perpetrators of grave breaches, including on the basis of universal jurisdiction if needed. As the EU has manifested its interest in ensuring respect for IHL with the adoption of the Guidelines on promoting compliance with IHL, the objective of this article is to analyze whether and to what extent the EU has developed instruments facilitating domestic prosecution of alleged war criminals pursuant to the Geneva Conventions.

KEYWORDS: European Union - international humanitarian law - universal jurisdiction grave breaches - war crimes.

\footnotetext{
* $\mathrm{PhD}$ in Law at the Autonomous University of Barcelona with research stays at UC Berkley and Paris I. Masters of Laws at the University of Montpellier. Lawyer linguist at the European Institute of Public Administration (EIPA).
} 


\section{Introduction}

Common Article 1 to the four Geneva Conventions establishes an obligation to ensure respect for International Humanitarian Law (hereinafter, IHL) at all times. This summary obligation has developed over the decades and is now understood to enshrine a mechanism of 'collective responsibility' whereby all State parties commit to adopt all the necessary and reasonable measures to prevent and stop violations of IHL, but also to prosecute them when they amount to war crimes. This third dimension is contained in Articles 49/50/129/146 of the four Geneva Conventions, which impose an obligation on its State parties to extradite or prosecute (aut dedere aut judicare) alleged perpetrators of grave breaches, including on the basis of universal jurisdiction if deemed necessary. ${ }^{2}$ Over time, the regime has evolved, most notably as a competing system of criminal responsibility - over war crimes - has developed at the international level. ${ }^{3}$ The grave breaches mechanism has indeed produced mixed results, but it certainly remains relevant when assessing the instruments established at domestic level to prosecute alleged contraveners of IHL.

While the EU lacks competence in this matter, its potential in implementing the aut dedere aut judicare principle in relation to violations of IHL should not be disregarded. Indeed, from a constitutional perspective, this question has become an EU concern, given its ambition to become a leader in human rights on the international stage, as established by Articles 2, 3, and 21 TEU. In this sense, participating in the fight against impunity is a component of the rule of law and a fundamental aspect of the respect for fundamental rights. In this context, the EU has extensively developed a policy of promotion and ensuring support to international criminal justice in general $^{4}$ and contemporaneously acknowledging that national prosecution is not only a priority, but also a consequence of the creation of the International Criminal Court (hereinafter, ICC). The EU therefore recognizes that EU Member States must cooperate with the ICC pursuant to the principle of complementarity. This concern is all the more relevant with regard to violations of IHL, as the EU seems to have endorsed the obligation to ensure respect for IHL, notably with the adoption of

\footnotetext{
${ }^{1}$ Laurence Boisson de Chazournes, Luigi Condorelli "Common Article 1 of the Geneva Conventions revisited: Protecting collective interests”, International Review of the Red Cross 837 (2000): 67-87.

2 "Each High Contracting Party shall be under the obligation to search for persons alleged to have committed, or to have ordered to be committed, such grave breaches, and shall bring such persons, regardless of their nationality, before its own courts. It may also, if it prefers, and in accordance with the provisions of its own legislation, hand such persons over for trial to another High Contracting Party concerned, provided such High Contracting Party has made out a prima facie case. Each High Contracting Party shall take measures necessary for the suppression of all acts contrary to the provisions of the present Convention other than the grave breaches defined in [Article 50 of the 1949 Geneva Convention I, Article 51 of the 1949 Geneva Convention II, Article 130 of the 1949 Geneva Convention III and Article 147 of the 1949 Geneva Convention IV]".

${ }^{3}$ Marko Divac Öberg, "The absorption of grave breaches into war crimes law", International Review of the Red Cross 91, no. 873 (2009): 163-83.

${ }^{4}$ See, e.g.: Jan Wouters and Basu Sudeshna, "The Creation of a Global Justice System: The European Union and the International Criminal Court" in The Effectiveness of International Criminal Tribunals, ed. Cédric Ryngaert (Antwerp: Intersentia, 2009); Florence Hartmann, "The ICTY and EU conditionality" in War crimes, conditionality and EU integration in the Western Balkans. Chaillot Paper $n^{\circ} 116$, ed. Judy Batt and Jelena Obradovic-Wochnik. (Paris: EU Institute for Security Studies, 2009); Antonis Antoniadis and Olympia Bekou, "The EU and the ICC: an awkward symbiosis in interesting times", International Criminal Law Review 7, n’. 4 (2008): 621-655; European Parliament, Mainstreaming Support for the ICC in the EU's Policies (2014).
} 
the 'Guidelines on promoting compliance with IHL' (hereinafter, IHL Guidelines). ${ }^{5}$ In this regard, the latter expressly refer to the fight against impunity, insinuating that the different operational means at the disposal at the EU to implement the Guidelines are also available on this matter.

Against this background, the objective of this article is to analyze whether, and to what extent the EU has developed instruments to facilitate the national prosecution of alleged war criminals in accordance with the aut dedere aut judicare principle.

In this context, the EU has adopted a range of tools to foster judicial cooperation among EU Member States to prevent the EU from becoming a safe haven for perpetrators, ${ }^{6}$ which echo the different components of the aut dedere aut judicare principle, as provided by the Geneva Conventions. Indeed, the EU has adopted several legal and policy measures that assist Member States in implementing their obligations to a) provide for effective penal sanctions; b) search out and investigate alleged perpetrators; c) prosecute, including on the basis of universal jurisdiction, and; d) to provide for extradition mechanisms in relation to violations of IHL, even though they necessarily need to be adapted to the EU special legal framework.

The endorsement at EU level of key principles of criminal law with regard to the violations of IHL is first examined and followed by an analysis of the different operational instruments established at EU level to assist Member States in implementing their obligation.

\section{Prosecuting violations of IHL: endorsement of key principles}

The EU has been an important promoter of international criminal law, including the fight against impunity regarding war crimes. It proclaims that it is committed to ending impunity for the most serious crimes and therefore, strongly supports the dissemination of international criminal law. Following the example of the UN, the EU projects the idea that peace may be achieved only if justice is made and alleged perpetrators of the most serious international crimes are prosecuted. ${ }^{7}$ EU Member States formalised this commitment to fight against impunity, including in several legally binding instruments.

\subsection{The fight against impunity as an EU objective}

In Council Common Position 2001/443/CFSP of 11 June 2001 on the International Criminal Court, they expressed that international core crimes are "of concern for all Member States" so that EU Member States should "cooperate for the prevention

\footnotetext{
${ }^{5}$ On this aspect, see: Bettina Steible, Chapter on "Externalizing European values: the case of International Humanitarian Law" in Pazy valores europeos como posible modelo de integración y progreso en un mundo global (Peter Lang, forthcoming 2018).

${ }^{6}$ Strategy of the EU Genocide Network to combat impunity for the crime of genocide, crimes against humanity and war crimes within the European Union and its Member States, 2014, 15581/1/14 Rev 1 (hereafter, 'EU Genocide Network Strategy'), 3; The Stockholm Programme, - An open and secure Europe serving and protecting citizens, OJ C 115/1 of 4 May 2010 (hereafter, 'Stockholm Programme'), 8.

${ }^{7}$ ICC, $7^{\text {th }}$ session of the Assembly of State parties, General debate, Declaration of Mr. Jean-François Blarel, Ambassador of France in the Netherlands, Head of Delegation, on behalf of the European Union, The Hague, 14 November 2008: “... une paix durable ne peut être réalisée si les exigences de la justice et la recherche des responsabilités individuelles pour les crimes internationaux les plus graves ne reçoivent pas une réponse appropriée".
} 
of those crimes and for putting an end to the impunity of the perpetrators thereof'. ${ }^{8}$ The fight against impunity was then enshrined as an objective in the Stockholm Program, in which EU institutions are invited to "continue support and promote Union and Member States' activity against impunity and to fight against crimes of genocide, crimes against humanity and war crimes". ${ }^{10}$ Finally, Council Decision 2011/168/CFSP of 21 March 2011 endorsed these statements, as its Recital also states that "[t]he Union and its Member States are determined to put an end to the impunity of the perpetrators of those crimes by taking measures at national level and by enhancing international cooperation to ensure their effective prosecution". ${ }^{11} \mathrm{It}$ is also worth mentioning in this regard that the EU established an annual 'EU Day against impunity', which aims to raise awareness on international core crimes, to promote prosecution, as well as to "appropriately recognize the common efforts of the EU Member States and the European Union in enforcing international criminal law". ${ }^{12}$

The fight against impunity is understood as one component of the EU's prior objectives in particular regarding the EU's founding values and its commitment towards the universal principles of liberty, democracy, the rule of law, human rights, and fundamental freedoms. ${ }^{13}$ EU Member States made this commitment clear on several occasions, using the provisions on the EU's founding values and on their externalisation as the legal basis for the EU's action on this matter.

By way of example, the Recital of Council Common Position 2001/443/CFSP refers to "the consolidation of the rule of law and respect for human rights, as well as the preservation of peace and the strengthening of international security" as the EU legal basis to act on this matter. It then explicitly integrates the principles of the Rome Statute into the EU's objectives " $[. .$.$] the principles of the Rome Statute of the International Criminal$ Court, as well as those regulating its functioning, are fully in line with the principles and objectives of the EU'. ${ }^{14}$ In Council Decision 2011/168/CFSP of 21 March 2011, the EU Member States confirmed and further detailed those elements, as they based their Decision on Article 21 of the Treaty on the European Union: "In its action on the international scene, the Union seeks to advance the principles of democracy, the rule of law, the universality and indivisibility of human rights and fundamental freedoms, respect for buman dignity, equality and solidarity, and respect for the principles of the United Nations Charter and international law, as provided for in article 21 of the Treaty". ${ }^{15}$ For a more recent example on the matter, EU Member States explicitly reiterated this commitment in 2016 in their 'Conclusions on the fight against impunity for the crime of genocide, crimes against humanity and war crimes within the European Union and its Member States'. The Recital states that the EU “... is founded on the values of liberty, democracy, the rule of law and respect for human rights" ${ }^{16}$ Consequently,

\footnotetext{
${ }^{8}$ Council Common Position 2001/443/CFSP of 11 June 2001 on the International Criminal Court, OJ L 150 of 18.6.2003, 67-9, Recital 4.

9 The Stockholm Programme was adopted on 4 May 2010. It established the priorities of the EU in the area of freedom and security for the period 2010-2014 and replaced the Hague Programme. See: The Stockholm Programme - An open and secure Europe serving and protecting citizens, OJ C 115/1 of $04.05 .2010,1-38$.

${ }^{10}$ Stockholm Programme, 8.

${ }^{11}$ Council Decision 2011/168/CFSP of 21 March 2011, OJ L 76 of 22.03.2011, 56, recital 6.

${ }^{12}$ Presidency report of the EU Day against impunity of genocide, crimes against humanity and war crimes, 23 May 2016, Eurojust, The Hague (10233/16).

${ }^{13}$ Wouters and Sudeshna, "The Creation of a Global Justice System...", 5.

${ }^{14}$ Council Common Position 2001/443/CFSP of 11 June 2001 on the International Criminal Court, OJ L 150 of 18.6.2003, 67-69, Recital 3.

${ }^{15}$ Council Decision 2011/168/CFSP of 21 March 2011, OJ L 76 of 22.03.2011, 56, recital, para. 1.

${ }^{16}$ Council Conclusions on fight against impunity for the crimes of genocide, crimes against humanity
} 
the codification of the EU's founding values and of their externalization has not become dead letter. Rather, they serve as the legal basis for the EU's action in the fight against impunity on the international scene. The EU therefore, explicitly legitimises its action on this matter on the basis of Article 2 TEU.

This commitment extends to violations of both IHL and International Human Rights Law (hereinafter, IHRL), in particular, with regards to the so-called 'core international crimes'. It is manifested both externally and internally. In this respect, the EU has used its CFSP to promote the fight against impunity on the international stage, notably through the adoption of guidelines. The IHL Guidelines are of utmost importance in this regard, but it is also possible to refer to the 'Guidelines to the EU policy toward third countries, on torture and other cruel, inbuman or degrading treatment or punishment, ${ }^{17}$ the 'EU Guidelines on Children and Armed Conflict, ${ }^{18}$ or the 'EU Guidelines on violence against women and girls and combating all forms of discrimination against them'. ${ }^{19}$

\subsection{A general endorsement of international criminal responsibility over war crimes}

Firstly, the EU has recognized, although in general terms, the concept of individual criminal responsibility for international crimes. In this context, what is touched upon is the regulation of the status of the alleged perpetrator in the sense that it has consistently supported the recognition of international criminal responsibility over violations of IHL. This commitment is formalised in the IHL Guidelines, "Individuals bear personal responsibility for war crimes. States must, in accordance with their national law, ensure that alleged perpetrators are brought before their own domestic courts or handed over for trial by the courts of another State or by an international criminal tribunal, such as the International Criminal Court". ${ }^{20}$ Even though the formulation is quite vague, it reminds an essential element of international law which has further been reiterated in numerous declarations.

As for immunity, some recommendations are addressed to EU Member States in the EU 'Genocide Network Strategy to combat impunity for the crime of genocide, crimes against bumanity and war crimes within the European Union and its Member States'. The underlying premise is that immunity should not be understood as allowing safe havens on EU territory, thus encouraging EU Member States to develop "national guidelines in line with international standards and clarify this area of law applicable to relevant ministries and criminal justice authorities". ${ }^{21}$ It is likewise interesting to note that the 2013, "Toolkit for bridging the gap between international and national justice', elaborated within the frame of its external action, states that the official capacity as a Head of State or government or a member of Government or Parliament shall, in no case, exempt a person from criminal responsibility in national law "as there should be no exceptions in the fight against impunity", while recognizing that this may involve constitutional issues, which "may

and war crimes within the European Union and its Member States (15584/2/14), 15-16 June 2015.

${ }^{17}$ Council of the European Union, Guidelines to EU Policy towards third countries on torture and other cruel, inhuman or degrading treatment or punishment - An up-date of the Guidelines (6129/1/12), Brussels, 20.03.2012.

${ }^{18}$ Council of the European Union, Update of the EU guidelines on children and armed conflict, 16.06.2008.

${ }^{19}$ Council of the European Union, EU Guidelines on violence against women and girls and combating all forms of discrimination against them, 08.12.2008.

${ }^{20}$ IHL Guidelines, para. 13/14.

${ }^{21}$ EU Genocide Network Strategy, Measure 4. 
need to be resolved, either by interpretation or amendment". ${ }^{22}$

Secondly, EU Member States formalised their recognition of the notion of war crimes in the IHL Guidelines, in which they underlined the necessity to prosecute such crimes. In this regard, even though the wording of the Guidelines is quite vague, it refers to several key concepts. In particular, it recognizes that certain "serious violations of IHL are defined as war crimes", thereby acknowledging the link existing between IHL and international criminal law, two branches of international law which meet at the notion of war crimes. ${ }^{23}$ By giving its opinion on numerous declarations where it has called for the repression of serious violations of IHL and the need to prosecute their perpetrators, ${ }^{24}$ the Union has initiated a movement followed progressively by international organizations and States, which culminated in the creation of international ad hoc tribunals and the adoption of the Statute of Rome. ${ }^{25}$

The EU recognizes international criminal law as forming part of IHL. The list of "principal legal instruments of IHL" contained in the Annex of the IHL Guidelines refers to the statutes of the ICTY, ICTR, and ICC. ${ }^{26}$ In the same line, in the document on the 'Use of Force Concept for EU-led Military Crisis Management Operations', the EU confirms that the Statute of the ICC is an integral part of IHL: "References to the Law of Armed Conflict (LOAC) or International Humanitarian Law (IHL) are deemed to include, where applicable, inter alia, the Geneva Conventions of 12 August 1949, the Protocols additional to these Conventions of 8 June 1977 and the Statute of the International Criminal Court, Rome, 17 July 1998". ${ }^{27}$ The latter example is significant in the sense that the Rome Statute is the only legal text not belonging to IHL which is referred to, and no mention is made to the 1907 Hague Regulations in the text of the IHL Guidelines, ${ }^{28}$ even though they are considered the most important IHL treaty norms alongside the Geneva Conventions. On another level, the 2009 'Council Conclusions on promoting compliance with IHL' highlight the importance of criminalizing serious violations of IHL: "The Council affirms its strong opposition to impunity for serious violations of international bumanitarian law and human rights law. (...) The Council emphasizes the importance of dealing effectively with the legacy of serious violations of international humanitarian and human rights law

\footnotetext{
${ }^{22}$ European Commission, High Representative of the European Union for Foreign Affairs and Security Policy, Joint Staff Working Document on advancing the principle of complementarity, Toolkit for bridging the gap between international and national justice, SWD(2013) 26 final, Brussels, 31.01.2013, 19.

${ }^{23}$ Council of the European Union, Guidelines to EU Policy towards third countries on torture and other cruel, inhuman or degrading treatment or punishment - An up-date of the Guidelines (6129/1/12), Brussels, 20.03.2012.

${ }^{24}$ See, e.g.: Declaration by the High Representative Catherine Ashton on behalf of the European Union on Libya, Brussels, 23 February 2011, 6966/1/11 REV 1 PRESSE 36; Council conclusions on Côte $d^{\prime}$ Ivoire, $3065^{\text {th }}$ Foreign Affairs Council meeting, Brussels, 31 January 2011; Declaration by the High Representative for Foreign Affairs and Security Policy Catherine Ashton on behalf of the European Union on the Office of the High Commissioner for Human Rights (OHCHR) Report of the Mapping Exercise documenting the most serious violations of human rights and international humanitarian law committed within the territory of the Democratic Republic of the Congo between March 1993 and June 2003, 6 October 2010, Brussels; Council Conclusions on Sri Lanka, 2942 ${ }^{\text {nd }}$ General Affairs Council Meeting, Brussels, 18 May 2009; EU annual report on human rights 2008, 175.

${ }^{25}$ Tristan Ferraro, "Le Droit International Humanitaire dans la Politique Étrangère et de Sécurité Commune de l'Union Européenne”, Revue Internationale de La Croix Rouge 84 (2009): 448.

${ }^{26}$ IHL Guidelines, Annex.

${ }^{27}$ Use of Force Concept for EU-led Military Crisis Management Operations - ${ }^{\text {st }}$ revision, Brussels, 28 February 2006, 6877/06, EXT 1 (31.03.2010).

${ }^{28}$ IHL Guidelines, para. 8.
} 
by supporting appropriate accountability mechanisms". ${ }^{29}$ As a result, international criminal law is understood as an integral part of IHL. By doing so, the EU participates in the international consensus on the criminalisation of the most serious violations of IHL on a conceptual level and thus, reinforces the opinio juris in this sense.

In this context, the IHL Guidelines refer to the notion of war crimes in broad terms "Certain serious violations of IHL are defined as war crimes. War crimes may occur in the same circumstances as genocide and crimes against humanity but the latter, unlike war crimes, are not linked to the existence of an armed conflict'. ${ }^{30}$ With this wording, the EU emphasizes the close relationship between war crimes, genocides and crimes against humanity. They all are considered the most serious violations of international law and are punishable, not only at national level, but also at the international level. However, the Guidelines do not provide for a definition of all these crimes. Instead of defining what war crimes, genocide and crime against humanity are, the Guidelines underline their differences in terms of ratione temporis only.

Nonetheless, it is worth mentioning that the EU's practice seems to have focused on the notion of 'war crimes', instead of those of 'grave breaches' and 'serious violations', typical of IHL. The wording of the Guidelines does not seem to establish any kind of differentiated procedural regime, depending on the nature of the violation, as is the case in IHL. Indeed, the obligation to prosecute or extradite was designed with regards to grave breaches only. However, the Guidelines refer to war crimes and do not even mention the grave breaches in relation to the obligation. Therefore, even though the wording is quite imprecise, it seems to endorse the alignment of the procedural regime of war crimes occurring in international and non-international armed conflicts. In practice, the EU has called to hold the criminal responsibility of persons responsible for IHL violations, regardless of the nature of the armed conflict. ${ }^{31}$ Furthermore, the EU recognized the authority of the Rome Statute of the ICC by means of a Council Decision, ${ }^{32}$ so that it endorses the criminalisation of violations of IHL occurring both in international and noninternational armed conflicts, as enshrined in Article 8. Thus, through its practice and pursuant to the Guidelines, the EU participates in the movement of alignment of the legal regimes of international and non-international armed conflicts and focuses on the notion of 'war crimes'.

In addition, the EU, together with some active Member States, has proven to advocate successfully for the extension of the list of behaviors that may constitute 'war crimes'. On the occasion of the Review Conference of the Rome Statute of the ICC held in Kampala, Uganda, in 2010, the delegation of Belgium lobbied to include some new war crimes applying to armed conflicts not of an international character. Negotiations came out in the favor of the delegation of Belgium which materialised in three war crimes being added to the already long list of war crimes contained in the Rome Statute. These crimes are the following: employing poison or poisoned weapons; ${ }^{33}$ employing asphyxiating, poisonous or other gases, and all

\footnotetext{
${ }^{29}$ Council conclusions on promoting compliance with international humanitarian law, $2985^{\text {th }}$ Foreign Affairs Council meeting, Brussels, 8 December 2009.

${ }^{30}$ IHL Guidelines, para. 13/14.

${ }^{31}$ Ferraro, 447.

${ }^{32}$ Council Decision 2011/168/CFSP of 21 March 2011 on the International Criminal Court repealing Council Common Position 2003/444/CFSP, OJ L 76 of 22.03.2011, 56.

${ }^{33}$ Rome Statute of the International Criminal Court, 17 July 1998, 2187 UNTS 90, art. 8(2)(b)(xvii).
} 
analogous liquids, materials and devices, ${ }^{34}$ and employing bullets which expand or flatten easily in the human body such as bullets with a hard envelope which does not entirely cover the core or is pierced with incisions. ${ }^{35}$ The argument raised was notably that these crimes constitute "serious violation of the laws and customs applicable in armed conflicts not of an international character, as reflected in customary international law". ${ }^{36}$ The results of this Conference were acknowledged by the Council, ${ }^{37}$ which adopted a new Decision on the International Criminal Court, ${ }^{38}$ notably in order to integrate these new crimes in its policy action.

In the same line, the EU has focused on the criminalisation of sexual violence occurring in armed conflict. By way of example, it reaffirms the commitment to eliminate "all forms of discrimination and violence towards women and girls, notably by putting an end to impunity and ensuring the protection of civilians, especially women and girls, during and after armed conflicts, as IHL and IHRL impose the obligation to the States". ${ }^{39}$ It is recalled that, pursuant to the Rome Statute, rape, sexual slavery, forced prostitution, forced pregnancy, forced sterilization and any other form of sexual violence constitute war crimes when they are committed in situations of armed conflict and also, in some very specific circumstances, of crimes against humanity. ${ }^{40}$

Thus, the EU, a staunch supporter of the fight against impunity, considered the curtailment of sexual violence against women and girls to be one of its prior objectives. This political support has extended to, inter alia, war crimes, which are understood in accordance with the current state of international law, since they include not only 'grave breaches' but also 'serious violations' of IHL and entail new behaviors, such as sexual violence. Nonetheless, all these elements are quite vague due to the lack of competence of the EU to enact penal legislation on this matter.

\subsection{The EU's uneven support to universal jurisdiction}

The position of the EU towards universal jurisdiction is ambiguous. Indeed, the EU institutions' political support for the establishment of universal jurisdiction mechanisms at domestic level is uneven. Furthermore, the EU recognizes the importance of universal jurisdiction, but only with regard to non-EU nationals seeking to enter and reside in the EU and in non-legally binding provisions. In spite of that, the EU has financially supported several non-governmental organizations promoting universal jurisdiction.

Firstly, the EU's institutions political support to universal jurisdiction, inside and outside Europe, has been uneven. This is the case with the European Parliament, which has expressly done so on numerous occasions, by means of its resolutions. In this respect, it first stated such support unambiguously in a 2000 Resolution on

\footnotetext{
${ }^{34}$ Ibid. art. 8(2)(b)(xviii).

${ }^{35}$ Ibid. art. 8(2)(b)(xix).

${ }^{36}$ Rome Statute amendment proposals, Report of the Working Group on other amendments, RC/11, annex IV, accessed December 5, 2017, https://asp.icc-cpi.int/iccdocs/asp_docs/RC2010/RC-11Annex.IV-ENG.pdf.

${ }^{37}$ Council Conclusions on the Review Conference of the Rome Statute of the International Criminal Court, Kampala, Uganda, from 31 May to 11 June 2010, 25 May 2010.

${ }^{38}$ Council Decision 2011/168/CFSP of 21 March 2011 on the International Criminal Court repealing Council Common Position 2003/444/CFSP, OJ L 76 of 22.03.2011, 56.

${ }^{39}$ 6072/1/05 REV (Presse 19).

${ }^{40}$ Josiane Auvret-Finck, "L'utilisation du DIH dans les instruments de la PESC" in L'UE et Le Droit International Humanitaire, Colloque Nice 18-19 Juin 2009, ed. Anne-Laure Chaumette (Paris: Pedone, 2010), 54.
} 
the situation in East Timor in the following terms, "23. Considers that the Union should be committed to the principle of universal jurisdiction and no safe havens for the perpetrators of genocide, war crimes and crimes against humanity and torture; 24. Calls on the Member States to enact the necessary legislation to permit domestic prosecution of genocide, war crimes, crimes against bumanity and torture, regardless of where these crimes were committed' ${ }^{41}$

It is, therefore, interesting that the European Parliament endorsed the principle of universal jurisdiction and called on the EU to support it, but further enjoined EU Member States to enshrine it into their domestic legislation. In subsequent resolutions, the European Parliament has called on third States - most importantly the USA ${ }^{42}$ and the African Union Member States ${ }^{43}$ the EU, ${ }^{44}$ and EU Member States ${ }^{45}$ to codify and enforce universal jurisdiction. Furthermore, it has welcomed on several occasions "the progress made in the application of universal jurisdiction in some Member States" ${ }^{46}$ ith regard to proceedings taking place in Spain and the UK. Yet, it should be noted that the European Parliament remained silent regarding proceedings taking place in Belgium, Germany, or Spain against US, Chinese, Iranian, and Israeli officials. ${ }^{47}$

${ }^{41}$ European Parliament Resolution on the situation in East Timor, OJ C 54 of 25/02/2000, 97-98.

${ }^{42}$ European Parliament Resolution on Human Rights in the world in 2001 and European Union human rights policy (2001/2011(INI)), para. 44: "Calls on the Member States to appeal to all UN Member States, in particular the United States, to ratify or accede to the Rome Statute setting up the International Criminal Court and to enact effective universal jurisdiction legislation".

${ }^{43}$ European Parliament resolution on the Special Court for Sierra Leone: the case of Charles Taylor (P6_TA(2005)0059), OJ C 304 E of 01/12/2005, 408; European Parliament Resolution on impunity in Africa and in particular the case of Hissène Habré (P6_TA(2006)0101).

${ }^{44}$ European Parliament resolution of 26 April 2007 on the Annual Report on Human Rights in the World 2006 and the EU's policy on the matter (2007/2020(INI)), OJ C 74E of 20.3.2008, 753-775, para 137: "in pursuit of greater coherence of internal and external policies, encourages the Council, the Commission and the Member States to incorporate the fight against impunity for serious international crimes in the development of a common EU area of freedom, security and justice"; European Parliament resolution of 8 May 2008 on the Annual Report on Human Rights in the World 2007 and the European Union's policy on the matter (2007/2274(INI)), OJ C 271E of 12.11.2009, 7-31, para. 144.

${ }^{45}$ European Parliament resolution of 26 April 2007 on the Annual Report on Human Rights in the World 2006 and the EU's policy on the matter (2007/2020(INI)), OJ C 74E, 20.3.2008, 753-775, para 137: "Reiterates the importance of EU internal policy promoting adherence to international buman rights law and the need for Member States to legislate in a way consistent with, inter alia, the obligations arising out of the Geneva Conventions, the Convention against Torture, the Genocide Convention and the Rome Statute of the ICC"; European Parliament resolution of 8 May 2008 on the Annual Report on Human Rights in the World 2007 and the European Union's policy on the matter (2007/2274(INI)), OJ C 271E of 12.11.2009, 7-31, para. 144; European Parliament resolution of 17 November 2011 on EU support for the ICC: facing challenges and overcoming difficulties (2011/2109(INI)), OJ 2013/C 153 E/13, paras. 16 and 20: "Takes note of the Cooperation and Assistance Agreement between the EU and the ICC; calls on the EU Member States to apply the principle of universal jurisdiction in tackling impunity and crimes against bumanity, and bighlights its importance for the effectiveness and success of the international criminal justice system".

${ }^{46}$ European Parliament Resolution on the arrest of General Pinochet in London, OJ C 341 of 09.11.1998, 147; European Parliament Resolution on the proceedings against Ríos Montt, OJ 313 E of 20.12.2006, 465-6; European Parliament resolution of 26 April 2007 on the Annual Report on Human Rights in the World 2006 and the EU's policy on the matter (2007/2020(INI)), OJ C 74E of 20.3.2008, 753-75, para 137; European Parliament resolution of 8 May 2008 on the Annual Report on Human Rights in the World 2007 and the European Union's policy on the matter (2007/2274(INI)), OJ C 271E of 12.11.2009, 7-31, para. 144; European Parliament resolution of 17 November 2011 on EU support for the ICC: facing challenges and overcoming difficulties (2011/2109(INI)), OJ 2013/C 153 E/13, para. 16: "Welcomes the contribution of some EU Member States to the fight against impunity for the worst crimes known to humanity through the application of universal jurisdiction".

${ }^{47}$ Luc Reydams, The Application of Universal Jurisdiction in the Fight against Impunity (European Parliament: 2016): 10 . 
Furthermore, the EU's support of universal jurisdiction in its external action is mixed. While the EU conducts an important policy on the fight against impunity in its external relations, nonetheless, it has had to dilute its position with regard to universal jurisdiction, in response to the African Union's criticism of EU Member States' practice on the matter described as "abusive". ${ }^{48}$ In particular, African States held that "the exercise of universal jurisdiction by European states is politically selective against them", thus raising concerns over double standards. ${ }^{49}$ In this context, the EU and African Union established an advisory Technical Ad Hoc Expert Group on the Principle of Universal Jurisdiction, which issued a report on the matter in $2009 .{ }^{50}$ The following definition of universal jurisdiction was provided: "Universal criminal jurisdiction is the assertion by one state of its jurisdiction over crimes allegedly committed in the territory of another state by nationals of another state against nationals of another state where the crime alleged poses no direct threat to the vital interests of the state asserting jurisdiction. In other words, universal jurisdiction amounts to the claim by a state to prosecute crimes in circumstances where none of the traditional links of territoriality, nationality, passive personality or the protective principle exist at the time of the commission of the alleged offence". ${ }^{51}$

Moreover, it recognizes that this is a principle which finds its legal basis both in international treaty law - with special reference to the Geneva Conventions and Additional Protocol I - and customary law. Furthermore, it is deemed to apply to, inter alia, war crimes. ${ }^{52}$ On the overall, the report endorsed important but vague principles. ${ }^{53}$ Political and diplomatic consequences of the use of universal jurisdiction are also addressed, as the experts recommend the States to "bear in mind the need to avoid impairing friendly international relations". ${ }^{54}$

This mixed endorsement is visible in other EU documents dealing with its external action. By way of example, in the 2009 annual report on the main aspects and basic choices of the CFSP, universal jurisdiction is explicitly mentioned as a "national instrument in the fight against impunity". ${ }^{55}$ However, the report also emphasizes that this issue has "negative consequences for the relationships between EU and AU". ${ }^{56}$ In the 2013 'Toolkit for Bridging the gap between international and national justice', universal jurisdiction is seen as a means to "reduce the risk of impunity", in accordance with national authorities' duty to prosecute alleged perpetrators of international core crimes by virtue of the principle of complementarity. ${ }^{57}$ Nonetheless, no further details are provided on that matter.

\footnotetext{
${ }^{48}$ Council of the European Union, AU-EU Technical Ad Hoc Expert Report on the Principle of Universal Jurisdiction, 8672/1/19, Brussels, 16 April 2009, 4.

${ }^{49}$ Council of the European Union, AU-EU Technical Ad Hoc Expert Report..., 35.

${ }^{50}$ Council of the European Union, AU-EU Technical Ad Hoc Expert Report..., 4.

${ }^{51}$ Council of the European Union, AU-EU Technical Ad Hoc Expert Report..., 6.

${ }^{52}$ Council of the European Union, AU-EU Technical Ad Hoc Expert Report..., 6-9.

${ }^{53}$ Marco Sassòli and Djemila Carron, "EU Law and International Humanitarian Law" in A Companion to European Union Law and International Law, ed. Dennis Patterson and Anna Södersten (John Wiley \& Sons: 2016), 419.

${ }^{54}$ Council of the European Union, AU-EU Technical Ad Hoc Expert Report on the Principle of Universal Jurisdiction, 8672/1/19, Brussels, 16 April 2009, 42.

${ }^{55}$ Council of the European Union, Annual report from the High Representative of the European Union for Foreign Affairs and Security Policy to the European Parliament on the main aspects and basic choices of the CFSP, 10659/10, Brussels, 8 June 2010, 49.

${ }^{56}$ Council of the European Union, "Annual report from the High Representative...".

${ }^{57}$ European Commission; High Representative of the European Union for Foreign Affairs and Security Policy, Joint Staff Working Document on advancing the principle of complementarity. Toolkit for Bridging the gap between international and national justice, Brussels, 31/01/2013, SWD(2013) 26 final, 19: "It is equally important to introduce in national law all the provisions which are necessary for the national
} 
In 2012, the European Commission expressed its view on universal jurisdiction on behalf of the EU in an amicus brief presented before the US Supreme Court, in relation with the case 'Kiobel vs. Royal Dutch Petroleum Co ${ }^{58}$ Even though this case concerned a civil suit for damages under the Alien Tort Statute, the Commission elaborated on universal criminal jurisdiction.

In this brief, it provides for a quite general definition of universal jurisdiction: "Universal criminal jurisdiction permits a State to prosecute universally condemned international crimes even when committed by aliens against aliens in the territory of another sovereign". ${ }^{59} \mathrm{~A}$ pure form of universal jurisdiction is, therefore, acknowledged. In addition, the Commission refers to the concept of an erga omnes obligation, to the extent that it grounds universal jurisdiction on the rationale according to which "the universally condemned crimes to which it extends are so repugnant that all States have a legitimate interest and therefore have the authority to suppress and punish them". ${ }^{60}$ It also highlights that "universal criminal jurisdiction is well established under international law". ${ }^{61}$ To illustrate such general acceptance, the Commission relies on International Treaty law, and for present purposes, on the Geneva Conventions and Additional Protocols. In particular, it acknowledges that such "treaties require States to extend universal jurisdiction over defined crimes where the alleged perpetrator is present within their territory". ${ }^{62}$ Consequently, it endorses the view, seemingly based on State practice, that the alleged perpetrator's presence on a State's territory is a requirement for the activation of universal jurisdiction mechanisms. As regards State practice, the Commission recognizes that it is "not widely exercised" 63 but that the fact that it does not "upset comity between nations" is another argument in favor of general acceptance. ${ }^{64}$ Nonetheless, it - surprisingly - uses the scarce number of prosecutions as an additional argument in this sense. ${ }^{65}$

Moreover, it is worth mentioning the EU Genocide Network Strategy, which, as noted above, has been endorsed by the Council. It expressly recognizes that the Geneva Conventions and Additional Protocols constitute the legal basis for "national authorities to seek out, investigate and prosecute or extradite those responsible for the commission of core international crimes, regardless of where they are committed, and irrespective of the nationality of the perpetrator or the victim". 66

Secondly, in strict legal terms, the EU's competence is quite limited, insofar as the exercise of universal jurisdiction remains a national competence. Nonetheless, there are references to universal jurisdiction at the EU level in 'Council Decision 2003/335/JHA of 8 May 2003 on the investigation and prosecution of genocide, crimes against bumanity, and war crimes', adopted within the frame of judicial cooperation in criminal

criminal courts to establish and exercise their jurisdiction. The adoption of legal provisions establishing extensive extraterritorial jurisdiction, or even universal jurisdiction, will reduce the risk of impunity. No State Party to the Rome Statute should accept to host on its territory someone who is suspected of having committed a crime falling within the jurisdiction of the ICC, wherever this crime has been committed".

${ }^{58}$ Luc Reydams, The Application of Universal Jurisdiction...,10.

${ }^{59}$ Supplemental Brief of the European Commission on behalf of the European Union at Amicus Curiae in Support of Neither Party, Supreme Court of the United States, Judgment of 13 June 2012,

Esther Kiobel et al., v. Royal Dutch Petroleum, 14.

${ }^{60}$ Ibid., 16.

${ }^{61}$ Ibid., 14.

${ }^{62}$ Ibid., 15.

${ }^{63}$ Ibid., 14.

${ }^{64}$ Ibid., 16.

${ }^{65}$ Ibid. Also observed in: Luc Reydams, The Application of Universal Jurisdiction..., 10.

${ }^{66}$ EU Genocide Network Strategy, 12. 
matters. In particular, Recitals (6) and (7) express such support as they refer to the obligation of EU Member States to extradite or prosecute alleged perpetrators from non-EU Member States accused of, inter alia, war crimes ${ }^{67}$ Therefore, there is some form of recognition at EU level of the obligation to establish universal jurisdiction mechanisms at domestic level with regard to non-EU citizens seeking to enter and reside in the EU. Luc Reydams interprets this recognition as an obligation on EU Member States "to establish jurisdiction over international crimes by non-EU citizens who are seeking to enter and reside in the EU" under current EU law. ${ }^{68}$ Nonetheless, it seems more appropriate to consider that there is no legal obligation to do so under current EU law, insofar as Recitals are not legally binding and Council Decision 2003/335/ JHA establishes a more limited obligation of cooperation among EU Member States on these matters. Consequently, it seems reasonable to assert that the support expressed in Recitals (6) and (7) is of a political - not legal - nature. In any event, these provisions would most likely apply to low-profile perpetrators, namely refugees and migrants who cannot and often do not want to be extradited, rather than former heads of State or government and other high-level officials. ${ }^{69}$

Finally, this uneven support in legal terms should not overshadow the important financial effort made by the EU on this matter. Indeed, the European Commission has financed several NGOs whose objective is to fight against impunity, including on the basis of universal jurisdiction: e.g., the Coalition for the International Criminal Court, No Peace without Justice, Parliamentarians for Global Action, Redress, Avocats Sans Frontières and the Fédération Internationale des Ligues des Droits de l'Homme. In conclusion, according to Luc Reydams, "grassroots support for universal jurisdiction (and the ICC) within and outside Europe has been partially underwritten by the EU". ${ }^{70}$

\section{Operational support to the fight against impunity at the internal level}

The EU has adopted a range of instruments to foster judicial cooperation among EU Member States, in order to ensure that the EU does not become a safe haven for perpetrators. ${ }^{71}$ In this regard, Article 8 of Council Decision 2011/168/ CFSP clarifies that the EU's commitment in the fight against impunity exists within the frame of its external action, but also extends to its internal policy: "The Union shall ensure consistency and coherence between its instruments and policies in all areas of its external and internal action in relation to the most serious international crimes as referred to in the Rome Statute".$^{72}$ Developing tools at internal level is indeed necessary in order to avoid, to the largest possible extent, accusations of double standards. If the EU

\footnotetext{
${ }^{67}$ Council Decision 2003/335/JHA of 8 May 2003 on the investigation and prosecution of genocide, crimes against humanity, and war crimes: “(6) Member States are being confronted on a regular basis with persons who were involved in such crimes and who are trying to enter and reside in the European Union. (7) The competent authorities of the Member States are to ensure that, where they receive information that a person who has applied for a residence permit is suspected of having committed or participated in the commission of genocide, crimes against humanity or war crimes, the relevant acts may be investigated, and, where justified, prosecuted in accordance with national law".

${ }^{68}$ Luc Reydams, The Application of Universal Jurisdiction..., 10.

${ }^{69}$ Luc Reydams, The Application of Universal Jurisdiction..., 20.

${ }^{70}$ Luc Reydams, The Application of Universal Jurisdiction..., 10.

${ }^{71}$ EU Genocide Network Strategy, 3; Stockholm Programme, 8.

${ }^{72}$ Council Decision 2011/168/CFSP of 21 March 2011 on the International Criminal Court and repealing Common Position 2003/44/CFSP, OJ L 76 of 22 March 2011, 58.
} 
were to succeed in compelling EU Member States to develop legislation on this matter, its efforts in the fight against impunity would be more credible, legitimate, and comprehensive. ${ }^{73}$

Even though the IHL Guidelines refer to the EU's external action, they are indicative of the EU's approach to the concepts that they implement. In particular, the EU specifically refers to the obligation to extradite or prosecute in the Guidelines on promoting compliance with IHL in the following terms: "Individuals bear personal responsibility for war crimes. States must, in accordance with their national law, ensure that the alleged perpetrators are brought before their own domestic courts or handed over for trial by the courts of another State or by an international criminal tribunal, such as the International Criminal Court". While the content of this clause is not exactly the same as the one contained in the Geneva Conventions, there is no doubt that it recalls the obligation to extradite or prosecute. First, it refers to the obligation to prosecute: "States must (...) ensure that the alleged perpetrators are brought before their own domestic courts...", and presents extradition as an alternative, including before international jurisdictions.

In parallel to the IHL Guidelines, the EU has adopted a series of legally binding instruments in relation to domestic prosecution of war crimes within the frame of the area of Freedom, Security and Justice. In particular, it is worth mentioning Council Decision 2002/494/JHA, which established a 'European network of contact points in respect of persons responsible for genocide, crimes against bumanity and war crimes' (hereinafter, 'EU genocide network'), Council Decision 2003/335/JHA of 8 May 2003 on the investigation and prosecution of genocide, crimes against humanity and war crimes, and the EU Framework Decision 2002/584/JHA of 13 June 2002 on the European Arrest Warrant. The adoption of such tools may be interpreted as a response to the commitment formalized by EU Members States in 2001 to work together to combat certain forms of crime. ${ }^{74}$

The purpose of Council Decision 2003/335/JHA is "to increase cooperation between national units in order to maximize the ability of law enforcement authorities in different Member States to cooperate effectively in the field of investigation and prosecution of persons who have committed orparticipated in the commission of genocide, crimes against humanity or war crimes as defined in Articles 6, 7 and 8 of the Rome Statute of the International Criminal Court of 17 Jub 1998" ${ }^{75}$ Therefore, an international commitment of the EU - cooperating with the ICC - is, in turn, used at the internal level in order to encourage EU Member States to take action on this issue. The Decision does not provide for precise obligations but solely establishes an obligation of cooperation regarding the exchange of information, ${ }^{76}$ investigation, and prosecution ${ }^{77}$ of individuals seeking residence in a Member State and allegedly accused of having committed an international core crime.

In the same line, the objective of Council Decision 2002/494/JHA is to make cooperation more efficient through the establishment of a EU Genocide Network within Member States' police and justice systems. ${ }^{78}$ Concretely, EU Member States

\footnotetext{
${ }^{73}$ EU Genocide Network Strategy, 24.

${ }^{74}$ Council Common Position of 11 June 2001 on the International Criminal Court (2001/443/CFSP), recital 4.

${ }^{75}$ Council Decision 2003/335/JHA of 8 May 2003 on the investigation and prosecution of genocide, crimes against humanity and war crimes, OJ L 118 of 14.5.2003, 12-14.

${ }^{76}$ Ibid. Art. 2.

${ }^{77}$ Ibid. Art. 3.

${ }^{78}$ Council Decision 2009/426/JHA of 16 December 2008 on the strengthening of Eurojust and amending Council Decision 2002/187/JHA setting up Eurojust with a view to reinforcing the fight
} 
must designate a contact point for the exchange of information concerning the investigation of international core crimes, including war crimes, as defined by the Rome Statute. ${ }^{79}$ These contact points must then provide information upon request or, on their initiative, that may be relevant in this context. Therefore, this Decision aims to establish the means of cooperation on this matter, as the actual investigation and prosecution fall under the remit of national authorities. ${ }^{80}$

In this context, a Secretariat was established in July 2011 within the staff of Eurojust, although it works as a separate unit. ${ }^{81}$ Furthermore, it is worth noting that the EU Genocide Network cooperates with institutions from third States. As such, it includes observers from Canada, Norway, Switzerland, and the USA and works with representatives from the ICC, ad hoc international criminal tribunals, the ICRC, Interpol, and civil society organizations. The EU Genocide Network further liaises with representatives from the European Commission and Eurojust. ${ }^{82}$ In addition, a Task Force composed of five contact points was established within this framework with a view to propose improvements in the fight against impunity's efficiency. ${ }^{83}$

The Task Force drafted a Strategy in this sense, published in $2014^{84}$ and endorsed by the Council in its Conclusions of 15-16 June 2015. ${ }^{85}$ Some elements of the Strategy are worth mentioning here. It is stated that the EU Genocide Network holds "a pivotal role in ensuring the EU's commitment to fighting impunity in the internal area" 86 and serves as a "best practice model for the development of similar networks in other regions" as is already the case in the African Union framework. ${ }^{87}$ In addition, it provides a set of measures addressed to EU institutions and Member States "to support national investigations and prosecutions of core international crimes". ${ }^{88}$

Concretely, the Strategy proposes several recommendations relating to procedures and the operational functioning of the fight against impunity at national level, such as implementing measures to improve the identification of cases and caserelevant information (Measure 2), facilitating cooperation among the "immigration, law enforcement, prosecution, mutual legal assistance, financial and intelligence authorities" as well as with civil society (Measure 3).

For present purposes, it is especially relevant mentioning the "desirability" of the creation of specialized units dealing exclusively with cases of core international crimes (Measure 1). This recommendation should, therefore, be read in conjunction with Council Decision 2003/335/JHA on the investigation and prosecution of genocide, crimes against humanity and war crimes, which recommended - already in 2003 - "to set up or designate specialist units within the competent law enforcement authorities with particular

\footnotetext{
against serious crimes, OJ L 138 of 04.06.2009, 12.

${ }^{79}$ Ibid., Art. 1.

${ }^{80}$ See: "Interview: EU a key player in ICC system", Global Justice, February 03, 2015, accessed December 5, 2017, https:/ /ciccglobaljustice.wordpress.com/2015/02/03/eu-a-key-player-in-icc-system/.

${ }^{81}$ Council Decision 2009/426/JHA of 16 December 2008 on the strengthening of Eurojust and amending Council Decision 2002/187/JHA setting up Eurojust with a view to reinforcing the fight against serious crimes, OJ L 138 of 04.06.2009, 14, art. 25a.

${ }^{82}$ EU Genocide Network Strategy, 24.

${ }^{83}$ Ibid., 4.

${ }^{84}$ Ibid.

${ }^{85}$ Council conclusions on fight against impunity for the crime of genocide, crimes against humanity and war crimes within the European Union and its Member States.

${ }^{86}$ EU Genocide Network Strategy, 24.

${ }^{87}$ Ibid., 25.

${ }^{88}$ Ibid., 32-45.
} 
responsibility for investigating and, as appropriate, prosecuting the crimes in question" ${ }^{99}$ At least Belgium, Croatia, Denmark, France, Germany, the Netherlands, Poland, Sweden, and the UK have created such units, which include officers specially trained to work in the identification, investigation or prosecution of, inter alia, war crimes, following a multidisciplinary approach. ${ }^{90}$ The creation of these units has proven to meaningfully improve the prosecution of alleged war criminals in the countries where they have established themselves. In this respect, the data presented in the Strategy on the number of completed and ongoing cases in EU Member States unsurprisingly reflect this reality, with the bulk of prosecutions taking place in the countries dotted with such specialized units. ${ }^{91}$

In the same way, Measure 4 explicitly refers to the need to improve domestic legislation relating to investigation, prosecution and mutual legal assistance so as to ensure that it appropriately reflects the current state of International Customary and Treaty law, in particular, with regards to the obligation to extradite or prosecute. It, likewise, refers to the necessity to codify, in domestic law, the definition of "core international crimes in accordance with international standards", to provide for "an exercise of extraterritorial, including universal, jurisdiction over those crimes", so that the legislation adequately transposes the notions of command or superior responsibility and "includes the relevant rules on the irrelevance of superior order defenses and statutes of limitation". ${ }^{22}$ Special mention is also made to the necessity not to use immunity as an undue protection of alleged perpetrators. The Strategy also refers to the necessity to include the different types of individual criminal responsibility for these crimes, namely command or superior responsibility, as well as the "relevant rules on the irrelevance of superior order defenses and statutes of limitation". ${ }^{93}$

Furthermore, other recommendations are addressed to the EU institutions, some of which have already been implemented. Inter alia, the EU Genocide Network recommends evaluating the implementation of Council Decision 2002/494/JHA and Council Decision 2003/335/JHA, to elaborate an Action Plan on the Fight against Impunity within the EU, or to assess additional funding possibilities in that framework. ${ }^{94}$ In that same line, it is worth noting that the proposal to create a European day against impunity for international crimes ${ }^{95}$ has been implemented.

Another instrument designed to enhance cooperation among EU Member States in relation to the fight against impunity is 'Framework Decision 2002/584/JHA of 13 June 2002 on the European arrest warrant and the surrender procedures between Member States. ${ }^{96}$ Even though framework decisions do not have direct effect, ${ }^{97}$ they oblige

\footnotetext{
${ }^{89}$ Council Decision 2003/335/JHA of 8 May 2003 on the investigation and prosecution of genocide, crimes against humanity and war crimes, OJ L 118 of 14.5.2003, 12-4, art. 4.

${ }^{90}$ EU Genocide Network Strategy, 27-9 and 33.

${ }^{91}$ Ibid., 30-32.

${ }^{92}$ Ibid., 40.

${ }^{93}$ Ibid., Measure 4.

${ }^{94}$ Ibid., 43.

${ }^{95}$ Ibid., 44.

${ }^{96}$ Luisa Vierucci, “The European Arrest Warrant: An Additional Tool for Prosecuting ICC Crimes”, Journal of International Criminal Justice 2 (2004): 275-285.

${ }^{97}$ Art. 34(2) of the Treaty of the European Union as amended by the Treaty of Nice reads as follows: "The Council shall take measures and promote cooperation, using the appropriate form and procedures as set out in this title, contributing to the pursuit of the objectives of the Union. To that end, acting unanimously on the initiative of any Member State or of the Commission, the Council may: [...] (b) adopt framework decisions for the purpose of approximation of the laws and regulations of the Member States. Framework decisions shall be binding upon the
} 
EU Member States "to reach the requested result and set a standard level by which to interpret different national criminal legislation". ${ }^{98}$ As such, they "generate a harmonizing effect on national criminal legislation within the Union". ${ }^{99}$ The Framework Decision on the European Arrest Warrant replaces formal extradition procedures among EU Member States with a system of mutual recognition of criminal decisions, referred to as the cornerstone of judicial cooperation. ${ }^{100}$ In particular, the purpose of the Framework Decision is to introduce "a new simplified system of surrender of sentenced or suspected persons for the purposes of execution or prosecution of criminal sentences" allowing one to "remove the complexity and potential for delay inherent in the present extradition procedures". ${ }^{101}$ The new system shall, therefore, aim to facilitate the "free movement of judicial decisions in criminal matters, covering both pre-sentence and final decisions, within an area of freedom, security and justice". ${ }^{102}$

To do so, the Framework Decision contains a list of offences, which "if they are punishable in the issuing Member State by a custodial sentence or a detention order for a maximum period of at least three years and as they are defined by the law of the issuing Member State, shall, under the terms of this Framework. Decision and without verification of the double criminality of the act, give rise to surrender pursuant to a European arrest warrant' ${ }^{\prime}{ }^{103}$ 'This list includes crimes within the ICC's jurisdiction. Therefore, this Framework Decision does not subject national authorities to the double jeopardy rule, nationality, and specialty requirements ${ }^{104}$ to hand over a suspect to another Member State. The Framework Decision on the European Arrest Warrant presents several advantages in the fight against impunity. It establishes a harmonised system of arrest and surrender throughout the EU "which is unprecedented in any other region of the world". ${ }^{105}$ More importantly, it allows national authorities to comply with their obligation to cooperate with the ICC without delay. Consequently, the Framework Decision has the potential to considerably facilitate proceedings whenever national authorities are willing to prosecute an alleged war criminal that has moved to another EU Member State.

Thus, even though the EU retains limited competence on this matter, it has established a series of tools that allow EU Member States to improve their cooperation in the apprehension and prosecution of persons suspected of having committed war crimes. Through these legal instruments, the EU, likewise, implements part of its obligation to ensure respect for IHL, insofar as it facilitates the work of national authorities to enforce Common Article 1 and Articles 49/50/129/146 of the four Geneva Conventions.

\footnotetext{
Member States as to the result to be achieved but shall leave to the national authorities the choice of form and methods. They shall not entail direct effect". Even though framework decisions no longer exist under the Lisbon Treaty architecture, their legal effects are preserved until they are repealed, annulled or amended. See: Protocol (n $\left.{ }^{\circ} 36\right)$ on Transitional Provisions, OJ 115 of 09/05/2008, 322-6, art. 9.

${ }^{98}$ ECJ, Judgment of 16 June 2005, Case 103/05, Criminal proceedings against Maria Pupino. Quoted in: Wouters and Sudeshna, "The Creation of a Global Justice System...”, 25.

${ }^{99}$ Wouters and Sudeshna, "The Creation of a Global Justice System...”, 25.

${ }^{100}$ EU Framework Decision 2002/584/JHA of 13 June 2002 on the European Arrest Warrant, OJ L $190 / 1$ of 18.07 .2002 , Preamble

${ }^{101}$ Ibid., recital 5.

102 Ibid.

${ }^{103}$ Ibid., art. 2.

${ }^{104}$ The last two requirements do meet exceptions, detailed in art. 4(6), 5(3), and 27. See: Luisa Vierucci, “The European Arrest Warrant: An Additional Tool for Prosecuting ICC Crimes”, 276.

${ }^{105}$ Luisa Vierucci, “The European Arrest Warrant...”, 277.
} 